\title{
CMV and Transplant-Related Coronary Atherosclerosis: An Immunohistochemical, In Situ Hybridization, and Polymerase Chain Reaction In Situ Study
}

Nadia V. Sambiase, Ph.D., Maria de Lourdes Higuchi, M.D., Gerard Nuovo, M.D., Paulo S. Gutierrez, M.D., Alfredo I. Fiorelli, M.D., David E. Uip, M.D., José A. Ramires, M.D.

Laboratory of Pathology (NVS, MdLH, PSG) and Clinical Division of Heart Institute (AIF, DEU, JAR), University of São Paulo Medical School, Brazil, and MGN Medical Research Laboratories (GN), Setauket, New York, USA

Accelerated graft coronary atherosclerosis is the main obstacle to long-term survival in patients who have had a heart transplant. A possible involvement of the human cytomegalovirus (HCMV) in this type of coronary atherosclerosis has been postulated by many authors but has not been definitively demonstrated. In an attempt to clarify the role of HCMV infection in the pathogenesis of this complication, we looked for in situ antigens or DNA of HCMV in 30 coronary artery segments obtained at necropsy from patients who had undergone orthotopic cardiac transplantation at the São Paulo Heart Institute. We tried to correlate these HCMV markers with the presence of inflammation and/or atherosclerosis in histologic sections. The patients were grouped as follows: GI, less than $\mathbf{1 7 0}$ days of graft survival and absent/mild atherosclerosis; GII, more than 170 days of graft survival and absent/mild atherosclerosis; GIII, more than $\mathbf{1 7 0}$ days of graft survival and severe/moderate atherosclerosis (170 days was the shortest graft survival time associated with atherosclerosis). The search for HCMV genome and antigens in the coronary artery sections was performed using immunohistochemistry, in situ hybridization, and polymerase chain reaction in situ techniques. Immunohistochemistry and in situ hybridization revealed no evidence of HCMV in all 30 cases. Polymerase chain reaction in situ revealed scarce HCMV-positive lymphocytes in two cases (one each from GI and GIII) located in the adventitial layer. These findings preclude a direct role for the HCMV in the pathogenesis of accelerated graft

Copyright (C) 2000 by The United States and Canadian Academy of Pathology, Inc.

VOL. 13, NO. 2, P. 173, 2000 Printed in the U.S.A.

Date of acceptance: September 1, 1999.

Address reprint requests to: Dr. Nadia V. Sambiase, Laboratório de Anatomia Patologica do Instituto do Coração, Hospital das Clínicas-FMUSP, Av. Dr. Eneas de Carvalho Aguiar, 44 05403-000 São Paulo, Brazil; e-mail: anpnadia@incor.usp.br; fax: 55-11-282-23-54. coronary atherosclerosis. However, the possibility of an indirect effect of the virus, such as an immune-mediated inflammatory response by the host that increases the expression of histocompatibility antigens, leading to tissue injury, cannot be excluded.

KEY WORDS: Accelerated atherosclerosis, Coronary arteriopathy, Cytomegalovirus, Heart transplantation, Immunohistochemistry, In situ hybridization, Polymerase chain reaction in situ.

Mod Pathol 2000;13(2):173-179

Contemporary immunosuppressive therapy, the use of endomyocardial biopsy to monitor for potential rejection, and the control of opportunistic infections have led to an improvement in the early survival rate of patients after heart transplantation. However, accelerated coronary artery disease (ACAD) is the major factor that limits the success of long-term engraftment. The registry of the International Society for Heart and Lung Transplantation shows that $40 \%$ of retransplants are due to chronic rejection and ACAD (1). Furthermore, the survival rates of patients who undergo retransplantation are significantly lower than those of patients who undergo primary heart transplantation (2).

Accelerated graft coronary atherosclerosis has some morphologic differences from native atherosclerosis. It is usually concentric and fibrocellular with involvement of the entire coronary tree, including the small branches $(3,4)$. It develops soon (6 months to 1 year) after heart transplantation, and risk factors for the usual form of atherosclerosis seem to participate little in its pathogenesis. Whereas the pathogenesis of such lesions is not well defined, immunologic mechanisms mainly related to rejection episodes seem to be involved in a milieu of nonimmunologic risk factors (5-7). Many authors have attributed an important role to the 
herpesvirus, particularly the human cytomegalovirus (HCMV), in the pathogenesis of this vasculopathy $(8-10)$. However, there are data that contradict this hypothesis (11-14). Whereas many studies have demonstrated possible links between herpesviruses and native atherosclerosis (15-18), data that demonstrate a relationship between the virus and the development of accelerated graft coronary atherosclerosis are fewer and inconclusive. In this study, we tried to clarify whether HCMV is directly involved in the pathogenesis of accelerated graft coronary atherosclerosis, using the very sensitive techniques of immunohistochemistry (IHC), in situ hybridization (ISH), and polymerase chain reaction in situ (PCR-IS) to locate HCMV antigens or genome in coronary artery segments obtained at necropsies from cardiac allograft recipients. These data were then correlated with histopathologic characteristics of the atherosclerotic lesions and clinical data to determine the presence of a relationship.

\section{MATERIALS AND METHODS}

\section{Casuistic}

We analyzed proximal and distal coronary artery segments obtained at necropsy from 30 cardiac pa- tients who had undergone heart transplantation at our institution and died between 1986 and 1994 . The postmortem interval before fixation ( $10 \%$ buffered neutral formalin-saline) ranged from 2 to $12 \mathrm{~h}$. These patients consisted of 23 males and 7 females, with a mean age of 43 years (range, 8 to 62 years). The graft survival times ranged from 0 to 1268 days, with a mean of 328 days. The primary diagnoses were idiopathic dilated cardiomyopathy in 15 patients, ischemic heart disease in 7, rheumatic disease in 5, and chronic Chagas' disease in 3. Pretransplant CMV serology was positive in 22 cases (73.3\%), negative in 4 cases $(13.3 \%)$, and not performed or found in 4 cases (13.3\%). The posttransplant active infection was found positive in 7 of 22 patients $(31.8 \%)$, and 3 of 7 patients $(42.8 \%)$ had clinical manifestation. Reactivation or active CMV infection was considered if IgM antibodies were present at serum or there was a 4 -fold increase in antibody titer of IgG or seroconversion of IgG antibodies or presence of CMV in any fluid (Table 1).

\section{Methods: Histopathologic Analysis}

Microscopic examination of the entire coronary artery tree was performed. Transverse sections that

TABLE 1. Clinical Data

\begin{tabular}{|c|c|c|c|c|c|c|c|c|c|}
\hline \multirow[b]{2}{*}{ Case } & \multirow{2}{*}{$\begin{array}{l}\text { Age } \\
(\mathrm{yr})\end{array}$} & \multirow[b]{2}{*}{ Sex } & \multirow{2}{*}{$\begin{array}{c}\text { Graft } \\
\text { Survival }\end{array}$} & \multirow{2}{*}{$\begin{array}{c}\text { Primary } \\
\text { Diagnosis }\end{array}$} & \multirow{2}{*}{$\begin{array}{l}\text { Rejection } \\
\text { Episodes }^{a}\end{array}$} & \multirow{2}{*}{$\begin{array}{l}\text { Death with } \\
\text { Infection }\end{array}$} & \multicolumn{3}{|c|}{ CMV Status } \\
\hline & & & & & & & $\begin{array}{l}\text { Serology } \\
\text { PreTx }\end{array}$ & $\begin{array}{c}\text { Active Infection } \\
\text { PosTx }\end{array}$ & $\begin{array}{l}\text { With Clinical } \\
\text { Manifestation }\end{array}$ \\
\hline 1 & 22 & $\mathrm{~m}$ & 49 & IDC & 0 & $\mathrm{Y}$ & - & - & - \\
\hline 2 & 28 & $\mathrm{~m}$ & 200 & CHD & 10 & $\mathrm{~N}$ & + & - & - \\
\hline 3 & 54 & $\mathrm{~m}$ & 3 & IHD & 0 & $\mathrm{~N}$ & NP & - & - \\
\hline 4 & 55 & $\mathrm{~m}$ & 56 & IHD & 1 & $\mathrm{~N}$ & + & + & - \\
\hline 5 & 44 & $\mathrm{f}$ & 37 & IDC & 1 & $\mathrm{Y}$ & NP & - & - \\
\hline 6 & 16 & f & 94 & $\mathrm{RD}$ & 0 & $\mathrm{Y}$ & + & + & - \\
\hline 7 & 34 & $\mathrm{~m}$ & 214 & IDC & 2 & $\mathrm{Y}$ & + & - & - \\
\hline 8 & 28 & $\mathrm{~m}$ & 19 & $\mathrm{CHD}$ & 0 & $\mathrm{~N}$ & + & - & - \\
\hline 9 & 48 & $\mathrm{~m}$ & 330 & IHD & 2 & $\mathrm{~N}$ & + & - & - \\
\hline 10 & 51 & $\mathrm{~m}$ & 25 & IDC & 0 & $\mathrm{Y}$ & - & - & - \\
\hline 11 & 38 & $\mathrm{~m}$ & 0 & IHD & 0 & $\mathrm{~N}$ & NP & - & - \\
\hline 12 & 35 & $\mathrm{~m}$ & 266 & IDC & 4 & $\mathrm{~N}$ & + & - & - \\
\hline 13 & 53 & $\mathrm{~m}$ & 466 & IDC & 1 & $\mathrm{~N}$ & + & - & - \\
\hline 14 & 40 & $\mathrm{f}$ & 182 & IDC & 1 & $\mathrm{~N}$ & + & - & - \\
\hline 15 & 25 & $\mathrm{~m}$ & 508 & IDC & 4 & $\mathrm{Y}$ & - & - & - \\
\hline 16 & 49 & $\mathrm{~m}$ & 1242 & IHD & 3 & $\mathrm{~N}$ & + & - & - \\
\hline 17 & 46 & $\mathrm{~m}$ & 1111 & IDC & 1 & $\mathrm{Y}$ & + & - & - \\
\hline 18 & 47 & $\mathrm{~m}$ & 1163 & IHD & 11 & $\mathrm{Y}$ & + & + & + \\
\hline 19 & 62 & $\mathrm{~m}$ & 178 & IDC & 2 & $\mathrm{Y}$ & + & + & + \\
\hline 20 & 52 & $\mathrm{f}$ & 47 & IDC & 0 & $\mathrm{~N}$ & + & + & + \\
\hline 21 & 40 & $\mathrm{~m}$ & 163 & $\mathrm{RD}$ & 0 & $\mathrm{Y}$ & $\mathrm{NP}$ & - & - \\
\hline 22 & 50 & $\mathrm{~m}$ & 263 & $\mathrm{RD}$ & 1 & $\mathrm{~N}$ & + & + & - \\
\hline 23 & 42 & f & 698 & IDC & 12 & $\mathrm{~N}$ & + & + & - \\
\hline 24 & 48 & f & 67 & IDC & 1 & $\mathrm{~N}$ & + & - & - \\
\hline 25 & 39 & $\mathrm{~m}$ & 611 & CHD & 3 & $\mathrm{Y}$ & + & - & - \\
\hline 26 & 23 & $\mathrm{~m}$ & 23 & IDC & 0 & $\mathrm{~N}$ & + & - & - \\
\hline 27 & 55 & $\mathrm{~m}$ & 60 & IHD & 0 & $\mathrm{~N}$ & + & - & - \\
\hline 28 & 23 & $\mathrm{~m}$ & 1268 & $\mathrm{RD}$ & 2 & $\mathrm{Y}$ & + & - & - \\
\hline 29 & 7 & $\mathrm{f}$ & 15 & IHD & 0 & $\mathrm{Y}$ & - & - & - \\
\hline 30 & 55 & $\mathrm{~m}$ & 486 & IDC & 4 & $\mathrm{Y}$ & + & - & - \\
\hline
\end{tabular}

CMV, cytomegalovirus; PreTx, pretransplant; PosTx, posttransplant; m, male; f, female; IDC, idiopathic dilated cardiomyopathy; CHD, chronic Chagas' disease; IHD, ischemic heart disease; RD, rheumatic disease; Y, yes; N, no; -, (negative); +, (positive); NP, not performed.

${ }^{a}$ Score: 0 to 12 (number of rejection episodes). 
showed major obstruction of the lumen were chosen from sections obtained $3 \mathrm{~cm}$ proximal and distal to the epicardial coronary arteries. Serial sections of this paraffin-embedded tissue were mounted on silane-coated glass slides for submission to four different techniques: histologic staining (hematoxylin and eosin), IHC, ISH, and PCR-IS.

\section{Group Assignments and Statistical Analysis}

On the basis of the atherosclerosis grade and graft survival time, we divided our 30 cases into three groups: GI, less than 170 days of graft survival and absent/mild atherosclerosis (Fig. 1A); GII, more than 170 days of graft survival and absent/mild (less than $50 \%$ obstruction of the lumen) atherosclerosis (Fig. 1B); GIII, more than 170 days of graft survival and severe/moderate atherosclerosis (Fig. 1C). (Note: 170 days was the shortest graft survival time associated with atherosclerosis causing greater than $50 \%$ obstruction of the lumen). Statistical analysis was performed using Spearman's rank correlation in an attempt to correlate the presence of HCMV with clinical data and histopathologic findings.

\section{Immunohistochemical Staining}

Enzymatic digestion was performed with $0.0015 \%$ trypsin (Sigma, St. Louis, MO) in phosphatebuffered saline (PBS), pH 7.6, for $10 \mathrm{~min}$ at $37^{\circ} \mathrm{C}$. The slides were then incubated overnight at $4^{\circ} \mathrm{C}$ with a 1:500 dilution of a monoclonal antibody anti-major-immediate-early antigen of HCMV, MAB-810, clone E13 (Chemicon International, Inc., Temecula, CA). Next, the sections were incubated for $30 \mathrm{~min}$ at $37^{\circ} \mathrm{C}$ with a secondary antibody, biotinylated rabbit antimouse (DakoPatts, Carpinteria, CA), diluted 1:400 in PBS. This was followed by incubation with a 1:200 dilution of streptavidinconjugated peroxidase (Amersham, UK) for $1 \mathrm{~h}$ at $37^{\circ}$ C. To develop the reaction, 3,3'-diamino- benzidine (Sigma) was used as a chromogen at a dilution of $0.04 \%$ in PBS and $0.036 \% \mathrm{H}_{2} \mathrm{O}_{2}$ as an enzyme substrate for $4 \mathrm{~min}$ at room temperature. Sections were counterstained with Gill's hematoxylin (Sigma). Between the incubations, the slides were rinsed three times for $5 \mathrm{~min}$ with PBS.

\section{In Situ Hybridization}

For the ISH, the sections were digested with proteinase K (GIBCO/BRL, Gaithersburg, MD) 0.125 $\mathrm{mg} / \mathrm{mL}$ in PBS-EDTA for 15 to $30 \mathrm{~min}$ at $37^{\circ} \mathrm{C}$. Then, $20 \mu \mathrm{l}$ of hybridization mixture was applied to the sections and spread by placing a glass coverslip over the section. The coverslips were sealed with a rubber cement to avoid evaporation of the mixture. The genomic biotinylated labeled HCMV-DNA probe (ENZO Diagnostics, New York, NY) is a mixture of two clones of CMV sequences, one cloned into the BamHI site of pIEI76 and the other cloned into the BamHI site of pUC18. The fragment size ranged from 100 to 1000 bp estimated by agarose gel electrophoresis. The double strands of the probe and DNA target were denatured by heating the slides on a dry block (ENZO) at $95 \pm 3^{\circ} \mathrm{C}$ for 5 min. Hybridization was performed for $2 \mathrm{~h}$ in a humidity chamber at $37^{\circ} \mathrm{C}$ with a hybridization cocktail containing the HCMV probe in $50 \%$ formamide, $50 \%$ dextran sulfate, $20 \times$ SSPE, and deionized water. Immediately after hybridization, the coverslips were removed by rinsing in PBS-EDTA plus $0.1 \%$ Triton-X-100. Then, the sections were incubated twice with a stringency solution, $2 \times$ SSC and $0.2 \times$ SSC for $15 \mathrm{~min}$ at $37^{\circ} \mathrm{C}$. The reaction was developed with a 1:300 dilution of streptavidin-peroxidase conjugate (Amersham Life Science) for $15 \mathrm{~min}$ at $37^{\circ} \mathrm{C}$ and the chromogen 3 -aminoethylcarbazole (Biomeda, Foster City, CA) for 5 min at room temperature. Sections were counterstained with Gill's hematoxylin for $5 \mathrm{~min}$ and mounted with Crystal Mount (Biomeda).
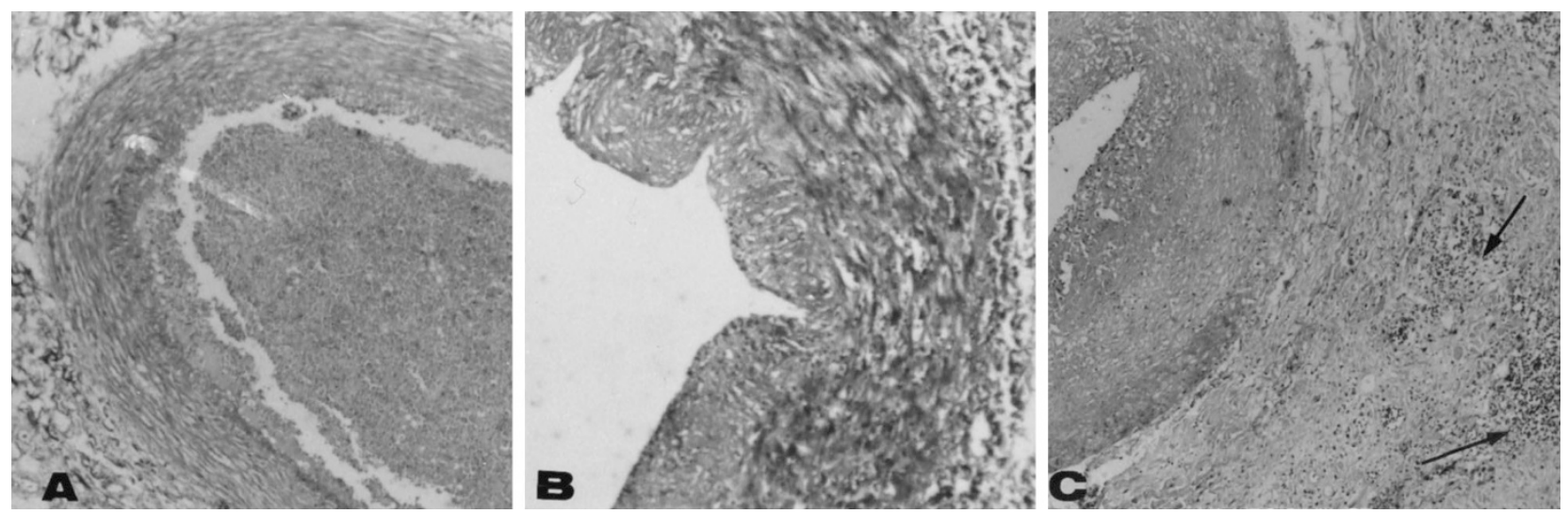

FIGURE 1. Microscopic views of coronary artery segments. A, Group I absent or mild intimal concentric thickening (0 to $25 \%$ of obstruction). B, Group II mild intimal concentric thickening (less than $50 \%$ of obstruction). C, Group III severe intimal concentric thickening (75\% of obstruction). This field shows severe adventitial lymphocytic inflammatory infiltrate of case 30 (arrows) (original magnification, 16×) . 


\section{Polymerase Chain Reaction In Situ}

Two serial tissue sections on the same slide were submitted to protein digestion with $2 \mathrm{mg} / \mathrm{mL}$ of pepsin (Boehringer Mannheim, Indianapolis, IN) for 25 min at room temperature. The PCR-IS protocol used was that described by Nuovo (19), using the 1000 thermal cycler (Perkin Elmer, Norwalk, CT). The PCR/ amplifying solution contained GeneAmp PCR buffer (Perkin Elmer); $4.5 \mathrm{~mm}$ magnesium; $200 \mathrm{~mm}$ each of deoxyadenosine triphosphate, deoxycytidine triphosphate, deoxyguanosine triphosphate, and deoxythymidine triphosphate; $1 \mathrm{~mm}$ of each of the primers; $0.006 \%$ of bovine serum albumin; water; and 5 U/50 $\mu \mathrm{l}$ of Taq polymerase. The primer pairs were complementary to genes located within the region of the viral genome that codes for the major immediate-early antigen region of HCMV (Towne strain) (Research Genetics, Inc., Huntsville, IL) (shown in Table 2). The PCR product was detected using the ISH technique. The probe (Research Genetics, Inc.) (shown in Table 2) was labeled with digoxigenin (Kit Genius, Boehringer Mannheim), and the detection was accomplished using an alkaline phosphatase-antidigoxigenin conjugate (1:50 dilution in $0.1 \mathrm{M}$ Tris $\mathrm{HCl}, \mathrm{pH} 7.4$, and 0.1 $\mathrm{MNaCl}$ ) for $30 \mathrm{~min}$ (Boehringer Mannheim). Then, the chromogen nitrobluetetrazolium and 5-bromo-4chloro-3-indolyl-phosphate was enzymatically transformed (room temperature for $10 \mathrm{~min}$ ) into a darkblue precipitate. The slides were counterstained for 5 min with fast red solution, which stains nuclei a pale pink (Boehringer Mannheim), and cover-slipped with Permount.

As a control for the reactions, we used human ovarian tissue previously known to be positive for HCMV obtained from necropsy and submitted to the same technical procedures of the coronary artery segments. An unrelated probe that did not correspond to a target in the cells (HSV-1 and 2, ENZO) was used as a negative control for ISH and PCR-IS to detect eventual nonspecific false-positive reactions. An amplification solution lacking primer pairs was also used on one section as a negative control for the PCR amplification.

\section{RESULTS}

Immunohistochemistry, In Situ Hybridization, and Polymerase Chain Reaction In Situ

IHC and ISH revealed no evidence of HCMV in all 30 of our cases $(100 \%)$ (Table 3 ) but demonstrated
HCMV positivity in the controls (Figs. 2A and B). PCR-IS detected HCMV structures in 2 of 21 cases (9.5\%), involving small lymphocytes in the adventitial layer (Table 3, Figs. 2D and E). These positive cells were associated with severe inflammation of the adventitia and concentric intimal thickening in Case 30 (Fig. 1C); however, no atherosclerosis or significant adventitial inflammation was observed in Case 6. A high number of HCMV-positive cells were found in the control, as expected (Fig. 2C).

\section{Histopathologic Findings}

The semiquantitative histopathologic findings were correlated with clinical data such as the graft survival time and number of episodes of acute rejection. Spearman's rank correlation test (Table 4) revealed a positive correlation between the number of rejection episodes and the presence of intimal thickening ( $P=.0003$, in proximal segment) and also between the presence of intimal thickening and fibrosis in the medial and adventitial layers $(P=.0001$ and $P=.0035$, respectively). The inflammatory infiltrate in the intimal layer was absent or mild in $70 \%$ of our cases and unrelated to the graft survival time $(P=.23)$. There was no correlation between the presence of HCMV and histopathologic characteristics of the intimal thickening.

\section{DISCUSSION}

In the present study, we used very sensitive in situ methods of detection to identify HCMV antigens or DNA in coronary artery wall segments obtained at necropsy from 30 patients who had had a heart transplant. Only PCR-IS demonstrated structures that were positive for HCMV. This DNAHCMV positivity occurred in small lymphocytes in the adventitia of two cases: one from Group III with moderate atherosclerosis and the other from Group I with no atherosclerosis. (The absence of atherosclerosis in the latter case could be explained by the brief posttransplant survival period of only 94 days.) The remaining cases showed no evidence of HCMV, and the positivity was limited to a few lymphocytes in the adventitia of only two cases. We therefore believe that there is no direct cause-andeffect relationship between the presence of CMV and the development of accelerated allograft atherosclerosis.

TABLE 2. Oligoprimer and Probe Sequences Used in the Detection of Human Cytomegalovirus by Polymerase Chain Reaction In Situ

\begin{tabular}{ll}
\hline \multicolumn{1}{c}{ Primers/Probe } & \multicolumn{1}{c}{ Sequence } \\
\hline MIE4CMV (sense) & $5^{\prime}$-CCA-AGC-GGC-CTC-TGA-TAA-CCA-AGC-C-3' \\
MIE5CMV (antisense) & $5^{\prime}$-CAG-CAC-CAT-CCT-CCT-CTT-CCT-CTG-G-3' \\
MIOPROBE & $5^{\prime}$-GAG-GCT-ATT-GTA-GCC-TAC-ACT-TTG-G-3' \\
\hline
\end{tabular}




\begin{tabular}{|c|c|c|c|c|}
\hline Groups & $\begin{array}{c}\text { Mean Graft } \\
\text { Survival (SD) }\end{array}$ & $\begin{array}{c}\text { IHC } \\
(n=30) \\
\text { Positive }\end{array}$ & $\begin{array}{c}\text { ISH } \\
(n=30) \\
\text { Positive }\end{array}$ & $\begin{array}{c}\text { PCR-IS } \\
(n=21) \\
\text { Positive }\end{array}$ \\
\hline Group I $(n=14)$ & 47 days (42.4) & 0 & 0 & 1 case \\
\hline Group II $(n=7)$ & 347 days (174.5) & 0 & 0 & 0 \\
\hline Group III $(n=9)$ & 866 days (434.7) & 0 & 0 & 1 case \\
\hline
\end{tabular}

IHC, immunohistochemistry; ISH, in situ hybridization; PCR-IS, polymerase chain reaction plus in situ hybridization.

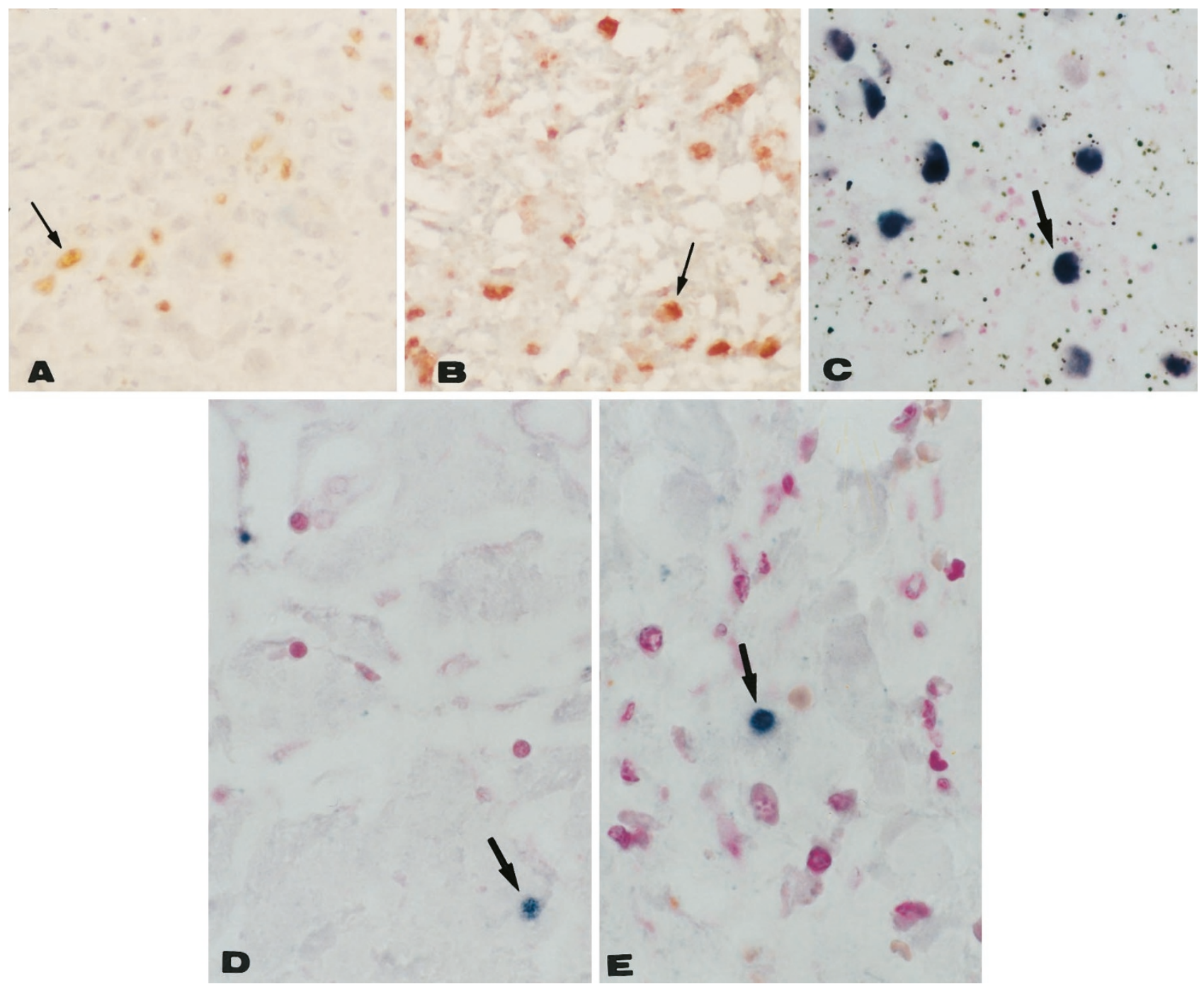

FIGURE 2. A-C, ovarian tissue (positive controls) showing several human cytomegalovirus-positive cells: A, Immunohistochemistry, stained in brown (3,3'-diaminobenzidine (arrow) (original magnification, $160 \times$ ); B, in situ hybridization, stained in red (3'-amino,g-ethylcarbazole) (arrow) (original magnification, $160 \times$ ); C, polymerase chain reaction in situ stained in dark blue (5-bromo-4-chloro-3-indolyl-phosphate) (arrow) (original magnification, $250 \times$ ). D and E, adventitial layer of coronary artery segments showing human cytomegalovirus DNA in a lymphocyte (arrows): D, polymerase chain reaction in situ in Patient 30 (original magnification, $400 \times$ ); E, polymerase chain reaction in situ in Patient 6 (original magnification, $400 \times)$.

Our results are in accordance with those of other groups that have identified CMV antigens or CMVDNA in endothelial cells, vascular smooth muscle cells, or cardiac muscle cells, but at very low positivity rates $(8,14,20)$. Gulizia et al. (14) used ISH and PCR to detect HCMV structures in human heart allografts, using hearts from trauma victims as a control group. They found HCMV positivity in 8 of 41 allografts (19.5\%) versus 1 of 22 hearts $(4.5 \%)$ in the control group. This difference was not statistically significant and indicates a low frequency of detectable HCMV genome in ACAD (14). In addition, Nadasdy and colleagues (13) found very low levels of CMV positivity in tubule cells when they used IHC, ISH, and PCR to perform a similar study in renal allograft specimens. They also found no association between CMV infection and obliterative transplant arteriopathy in cases of renal allograft rejection. 


\begin{tabular}{|c|c|c|c|c|}
\hline & $\begin{array}{c}\text { Intimal } \\
\text { Thickening }\end{array}$ & $\begin{array}{c}\text { Intimal } \\
\text { Inflammation }\end{array}$ & Medial Fibrosis & $\begin{array}{c}\text { Adventitial } \\
\text { Fibrosis }\end{array}$ \\
\hline \multirow[t]{2}{*}{ Graft survival } & $0.0007(\mathrm{P})$ & $0.2396(\mathrm{P})$ & $0.0007(\mathrm{P})$ & $0.0214(\mathrm{P})$ \\
\hline & 0.0459 (D) & $0.8610(\mathrm{D})$ & $0.0017(\mathrm{D})$ & $0.0128(\mathrm{D})$ \\
\hline \multirow[t]{2}{*}{ Rejection } & $0.0003(\mathrm{P})$ & $0.0380(\mathrm{P})$ & $0.0006(\mathrm{P})$ & $0.0360(\mathrm{P})$ \\
\hline & $0.0160(\mathrm{D})$ & 0.4975 (D) & $0.0108(\mathrm{D})$ & $0.0905(\mathrm{D})$ \\
\hline \multirow{2}{*}{ Medial fibrosis } & $0.0001(\mathrm{P})$ & $0.0073(\mathrm{P})$ & - & $0.0003(\mathrm{P})$ \\
\hline & $0.0331(\mathrm{D})$ & $0.2100(\mathrm{D})$ & & $0.0007(\mathrm{D})$ \\
\hline
\end{tabular}

$\mathrm{P}$, proximal coronary artery segment; $\mathrm{D}$, distal coronary artery segment. $P<.05$.

Our results differ from those of Gulizia et al. (14) regarding the detection of HCMV with ISH. Whereas we found no evidence of HCMV using ISH (0\%), Gulizia et al. (14) detected HCMV structures by ISH in four cases (17.4\%) but the DNA-HCMV was focally positive in the perivascular myocardium of two cases and only involved the adventitia and media of a coronary artery in the other two positive cases $(8.7 \%)$. This difference in ISH results could be due to our use of a nonradioactive probe versus the radiolabeled probe $\left({ }^{35} \mathrm{~S}\right)$ used by Gulizia et al. However, the idea that a radiolabeled probe maximizes the sensitivity of ISH is a misconception. Advances in nonisotopic labeling (biotin and digoxigenin) probes and detection systems have enhanced the sensitivity of the ISH technique (19). A lower number of viral copies are frequently present in our coronary artery sections, which could be demonstrated only by ISH after PCR.

Most of the evidence suggesting an association between infection with the herpes family of viruses (e.g., herpes simplex virus, CMV) and the development of native atherosclerosis or cardiac allograft vasculopathy comes from experimental works (8, $15,16,20)$. Normocholesterolemic chickens with Marek's disease, a disorder caused by an avian herpesvirus infection, developed occlusive atherosclerotic lesions (21). Hajjar (22) suggested that by penetrating cells of the vessel, the herpesvirus could induce alterations in lipid metabolic activity, leading to an accumulation of cholesterol. According to this mechanism, the virus should be found frequently in intimal thickenings. Lemströn et al. (23) observed decreased rates of ACAD in CMVinfected cardiac allograft rats treated with antiviral drugs.

Some clinical data have linked active HCMV infection in patients who have had a heart transplant with both an increased number of rejection episodes and the development of graft vasculopathy $(9,10,24)$. In contrast, Dummer et al. (25) investigated 314 patients who underwent cardiac transplantation and found no association between HCMV seropositivity and the presence of atherosclerosis. More recent, it has been shown that the
HCMV genome could interfere with the tumor suppressor gene $p 53$ that inhibits cell cycle progression, leading to cellular proliferation and coronary restenosis (26-28). This could be a possible way for HCMV to contribute to the development of ACAD.

In the present work, we can discard the notion that the apparent discrepancy between the clinical and laboratory data and pathologic findings regarding the frequency of HCMV detection is due to insufficient sensitivity of the techniques used. PCR-IS is the most sensitive technique for detecting DNA in histopathologic sections. Furthermore, we were able to localize precisely the few HCMVpositive lymphocytes to the adventitial layer among the inflammatory infiltrate. Different from other studies, the HCMV active infection is not a frequent and severe complication in our cardiac transplanted receptors (29). In the present casuistic, the active infection occurred in $31.8 \%$ detected by monitoring HCMV antibody titers in our patients during the posttransplant period. This finding could be explained by the high prevalence of HCMV seropositivity in the receptors $(82.85 \%$ of seropositivity in pretransplant period), which indicates that latent viral infection is a common finding in our patient population.

Recent studies have tried to demonstrate which tissues are harbor for viral DNA and the relative viral DNA load for each seropositive human's organs. They have found using the PCR-IS technique that latent HCMV-DNA is located in liver sinusoidal lining cells (30).

In summary, our data suggest that HCMV does not play a direct role in the pathogenesis of ACAD. However, an indirect role for HCMV cannot be ruled out. If HCMV really does contribute to the cause of ACAD, the best hypothesis is that the HCMV triggers vascular inflammation, which may favor the development of graft atherosclerosis.

Acknowledgments: This work was supported by Zerbini Foundation and, in part, by Fundação de Amparo à Pesquisa do Estado de São Paulo Grant 93/3090-5, Brazil. 


\section{REFERENCES}

1. Kriett JM, Kaye MP. The Registration of the International Society for Heart and Lung Transplantation: Seventh Official Report-1990. J Heart Lung Transplant 1990;9:323-30.

2. Ensley RD, Hunt S, Taylor DO, Renlund DG, Menlove RI, Karwande SV, et al. Predictors of survival after repeat heart transplantation: the Registry of the International Society for Heart and Lung Transplantation and contributing investigators. J Heart Lung Transplant 1992;11:S142-58.

3. Johnson DE, Gao SZ, Schroeder JS, Decampo WM, Billingham ME. The spectrum of coronary artery pathology findings in human cardiac allografts. J Heart Lung Transplant 1989;8:349-59.

4. Billinghan ME. Cardiac transplant atherosclerosis. Transplant Proc 1987;19(Suppl 5):19-25.

5. Dong C, Redenbach D, Woods S, Battistini B, Wilson J, McManus B. The pathogenesis of cardiac allograft vasculopathy. Curr Opin Cardiol 1996;11:183-90.

6. Johnson MR. Transplant coronary disease: nonimmunologic risk factors. J Heart Lung Transplant 1992;11:124-32.

7. Ventura HO, Mehra MR, Samart FW, Stapleton DD. Cardiac allograft vasculopathy: current concepts. Am Heart J 1995; 129(4):791-9.

8. Wu TC, Hruban RH, Ambinder RF, Pizzorno M, Cameron DE, Baumgartner WA, et al. Demonstration of cytomegalovirus nucleic acids in the coronary arteries of transplanted hearts. Am J Pathol 1992;140(3):739-47.

9. Grattan MT, Moreno-Cabral C, Starnes VA, Oyer PE, Stinson $\mathrm{EB}$, Shumway NE. Cytomegalovirus infection is associated with cardiac allograft rejection and atherosclerosis. JAMA 1989;261(24):3561-6.

10. McDonald K, Rector TS, Braulin EA, Kubo SH, Olivari MT. Association of coronary artery disease in cardiac transplant recipients with cytomegalovirus infection. Am J Cardiol 1989;64:59-362.

11. Pucci A, Ghisetti V, Donegani E, Barbui A, David E, Fortunato $\mathrm{M}$, et al. Histologic and molecular diagnosis of myocardial human cytomegalovirus infection after heart transplantation. J Heart Lung Transplant 1994;13(6):1072-80.

12. Ghisetti V, Barbui A, Rocci MP, Donegani E, Bobbio M, Pucci $\mathrm{A}$, et al. Detection of human cytomegalovirus myocardial involvement by polymerase chain reaction during systemic infection and correlation with pp65 antigenemia and Dnaemia in infected heart recipients. Transplantation 1996;61(7): 1072-5.

13. Nadasdy T, Smith J, Saszik Z, Warner J L, Johnson LD, Silva FG. Absence of association between cytomegalovirus infection and obliterative transplant arteriopathy in renal allograft rejection. Mod Pathol 1994;7(3):289-94.

14. Gulizia JM, Kandolf R, Kendall TJ, Thieszen SL, Wilson JE, Radio SJ, et al. Infrequency of cytomegalovirus genome in coronary arteriopathy of human heart allografts. Am J Pathol 1995;147(2):461-75.
15. Benditt EP, Barret T, McDougal JK. Viruses in the etiology of atherosclerosis. Proc Natl Acad Sci U S A 1983;80:6386-9.

16. Melnick JL, Dreesman GR, McCollum CH, Petrie BL, Burek J, Debakey ME. Cytomegalovirus antigen within human arterial smooth muscle cells. Lancet 1983;17:644-7.

17. Yamashiroya H, Ghosh L, Yang R, Robertson AL. Herpesviridae in the coronary arteries and aorta of young trauma victims. Am J Pathol 1987;130(1):71-9.

18. Hajjar DP, Pomerantz KB, Falcone DJ, Weksler BB, Grant AJ. Herpes simplex virus infection in human arterial cells: implications in atherosclerosis. J Clin Invest 1987;80:131721.

19. Nuovo GJ. PCR in situ hybridization: protocols and applications. 3rd ed. New York: Lippincott-Raven; 1996.

20. Hendrix MG, Daemaen M, Bruggeman CA. Cytomegalovirus nucleic acid distribution within the human vascular tree. Am J Pathol 1991;138(3):563-7.

21. Fabricant CG, Fabricant J, Minick CR, Litrenta MM. Herpesvirus-induced atherosclerosis in chickens. Fed Proc 1983;42(8):2476-9.

22. Hajjar DP. Viral pathogenesis of atherosclerosis: impact of molecular mimicry and viral genes. Am J Pathol 1991;139(6): 1195-211.

23. Lemströn KB, Bruning JH, Bruggeman CA, Koskinen PK, Aho PT, Yilmaz S, et al. Cytomegalovirus infection: enhanced allograft arteriosclerosis is prevented by DHPG prophylaxis in rat. Circulation 1994;90:(4):1969-78.

24. Mangiavacchi M, Frigerio M, Gronda E, Danzi GB, Bonacina E, Masciocco G, et al. Acute rejection and cytomegalovirus infection: correlation with cardiac allograft vasculopathy. Transplant Proc 1995;27(3):1960-2.

25. Dummer S, Lee A, Breining MK, Komos R, Ho M, Griffith, B. Investigation of cytomegalovirus infection as a risk factor for coronary atherosclerosis in the explanted hearts of patients undergoing heart transplantation. J Med Virol 1994;44:305-9.

26. Speir E, Huang ES, Modali R, Leon MB, Shawl F, Finkel T, et al. Interaction of human cytomegalovirus with p53: possible role in coronary restenosis. Scand J Infect Dis 1995;99(Suppl 99):78-81.

27. Speir SE, Speir S, Zhou YF, Guetta E, Leon M, Finkel T. The role of infection in restenosis and atherosclerosis: focus on cytomegalovirus. Lancet 1996;348:S13-7.

28. Zhou YF, Leon MB, Waclawiw MA, Popma JJ, Yu ZX, Finkel T, et al. Association between prior cytomegalovirus infection and the risk of restenosis after coronary atherectomy. N Engl J Med 1996;335(9):624-30.

29. Uip DE, Amato Neto V, Strabelli TM, Bocchi EA, Fiorelli AI, Stolf N, et al. Infections in 100 heart transplantation patients. Arq Bras Cardiol 1995;64(6):537-40.

30. Kroffon AJ, Patterson BK, Yan S, Kaufman DB, Fryer JP, Stuart FP, et al. Latent human cytomegalovirus: a functional study. Transplant Proc 1997;29:93-5. 